\title{
Key Measurement Concepts and Appropriate Clinical Outcome Assessments in Pediatric Achondroplasia Clinical Trials
}

Natalie Valerie Jane Aldhouse ( $\square$ natalie.aldhouse@clarivate.com )

Clarivate https://orcid.org/0000-0001-6573-7431

Helen Kitchen

Clarivate

Chloe Johnson

Clarivate

Chris Marshall

Clarivate

Hannah Pegram

Clarivate

Sheryl Pease

Pfizer Inc

\section{Sam Collins}

Pfizer Inc

Christine Lynn Baker

Pfizer Inc

Katherine Beaverson

Pfizer Inc

Chandler Crews

The Chandler Project

Jill Massey

Evelina London Children's Healthcare

Kathleen W Wyrwich

Pfizer Inc

\section{Research Article}

Keywords: Achondroplasia, patient-reported outcome, clinical outcome assessment, qualitative, pediatric, functioning

Posted Date: August 2nd, 2021 
DOl: https://doi.org/10.21203/rs.3.rs-744926/v1

License: (c) (1) This work is licensed under a Creative Commons Attribution 4.0 International License. Read Full License 


\section{Abstract}

Background: This study aimed to identify fit-for-purpose clinical outcome assessments (COAs) to evaluate physical function and social and emotional well-being in clinical trials enrolling a pediatric population with achondroplasia. Qualitative interviews lasting 90 minutes were conducted in the US with children/adolescents with achondroplasia and/or their caregivers. Interviews utilized concept elicitation methodology to explore experiences and priorities for treatment outcomes. Cognitive debriefing methodology explored relevance and understanding of selected COAs.

Results: Interviews $(N=36)$ were conducted with caregivers of children age $0-2$ years $(n=8)$ and $3-7$ years $(n=7)$ and child/caregiver dyads with children age $8-11$ years $(n=15)$ and $12-17$ years $(n=6)$.

Children/caregivers identified pain, short stature, impacts on physical functioning (e.g. reach), and impacts on well-being (e.g. negative attention/comments) as key bothersome aspects of achondroplasia. Caregivers considered an increase in height $(n=9 / 14,64 \%)$ and an improvement in limb proportion $(n=11 / 14,71 \%)$ as successful treatment outcomes. The Childhood Health Assessment Questionnaire (CHAQ) and Quality of Life in Short Stature Youth (QoLISSY-Brief) were cognitively debriefed. CHAQ items evaluating activities, reaching, and hygiene were most relevant. QoLISSY-Brief items evaluating reaching, height bother, being treated differently, and height preventing doing things others could were most relevant. The CHAQ and QoLISSY-Brief instructions, item wording, response scales/options and recall period were well understood by caregivers and adolescents age 12-17. Some children aged 8-11 had difficulty reading, understanding, or required caregiver input. Feedback informed minor amendments to the CHAQ and the addition of a seven-day recall period to the QoLISSY-Brief. These amendments were subsequently reviewed and confirmed in $N=12$ interviews with caregivers of children age $0-11(n=9)$ and adolescents age $12-17(n=3)$.

Conclusions: Achondroplasia impacts physical functioning and well-being. An increase in height and improvement in limb proportion are considered to be important treatment outcomes, but children/adolescents and their caregivers expect that a successful treatment should also improve important functional outcomes such as reach. The CHAQ (adapted for achondroplasia) and QoLISSYBrief are relevant and appropriate measures of physical function and emotional/social well-being for pediatric achondroplasia trials; patient-report is recommended for age 12-17 years and caregiver-report is recommended for age $0-11$ years.

\section{Background}

Achondroplasia is a rare genetic condition in which bone growth is impaired. More than 250,000 people are affected worldwide (1), approximately $80 \%$ of whom were born to average-height parents (2). People with achondroplasia have short stature, short arms with a limited range of motion, short thighs, an enlarged head, leg bowing, and hypermobile joints (hips, knees, shoulders), with the exception of the elbows, which are stiff and have a limited range of motion (2). Children with achondroplasia have a different schedule of developmental milestone attainment compared with children without 
achondroplasia (3) and may experience complications relating to impaired bone growth; craniocervical junction constriction and restrictive pulmonary disease can be of major concern during early infancy (2). Other complications may include recurrent ear infections, sleep apnea, teeth crowding/misalignment and speech and hearing difficulties (4).

Treatment to date has been limited to medical and surgical interventions aimed at correcting comorbidities associated with the condition, such as an osteotomy for bowing (5), spinal decompression for foramen magnum stenosis (6), tonsillectomy and/or adenoidectomy for obstructive apnea (7), and ear tube insertion for middle ear dysfunction (8). Uncommonly, limb-lengthening may be performed, but this is an invasive and time consuming process (9). However, novel pharmaceutical treatments are currently in development in clinical trials to directly address the underlying mechanism that causes the disordered bone growth in children with achondroplasia. To evaluate the impact of these investigational treatments on how patients feel and function, appropriate and relevant clinical outcome assessment $(\mathrm{COA})$ measures are required for inclusion in clinical trials.

FDA acknowledge that the development of new COAs is time consuming and has particular challenges in rare disease where there is an urgency to find new treatments (8). Consequently, FDA have indicated that is it not always necessary to 'start from scratch' and instead rare disease drug developers should look for 'fit for purpose' adjustments to endpoints for the needs of the patient group and look to measures already in use (10). The Critical Path patient-reported outcomes (PRO) Consortium's Rare Disease Subcommittee aim to develop fit-for-purpose endpoint measures in treatment trials for rare diseases, with the premise that existing COAs may usable or modifiable (11).

Therefore, to explore the need for a new instrument or a modifiable instrument, an initial review of qualitative literature (12-24), the transcript of a 2018 FDA advisory committee meeting discussing drug development for the treatment of children with achondroplasia (25), clinical expert interviews, and existing COA measures was conducted to gain an initial understanding of the lived experience of achondroplasia and review potentially relevant COAs. Two measures, the Childhood Health Assessment Questionnaire (CHAQ) and Quality of Life in Short Stature Youth (QoLISSY) Brief were selected for further investigation in this interview study. These two measures were selected based on conceptual coverage, with a focus on assessment of physical functioning and well-being, respectively. Additionally, patientreported and observer-reported outcome (ObsRO) versions of the CHAQ and QoLISSY-Brief were available which could allow some children/adolescents to self-report on their own condition. While caregiver report is necessary and appropriate for children who are too young or otherwise unable to report for themselves, patient-report for older children/adolescents should not be overlooked (26).

FDA's Patient Focused Drug Development (PFDD) Draft Guidance outlines best practices to ensure that a $\mathrm{COA}$ is fit for its intended purpose in medical product development so that the effects seen in clinical trials can be interpreted and communicated as a clear clinical benefit that is meaningful to patients (27). The process of selecting or developing a COA for use in a clinical development program depends on 
having adequately characterized the disease or condition, defined the target context of use, and conceptualized a concept of interest that represents clinical benefit (27).

This study therefore aimed to further contribute to the conceptualization of the lived experience of the pediatric population with achondroplasia. Additionally, this study aimed to evaluate the appropriateness and relevance of the CHAQ and QoLISSY-Brief as measures of impact on physical functioning and wellbeing in children and adolescents living with achondroplasia.

\section{Methods}

\section{Recruitment}

This cross-sectional, non-interventional, qualitative interview study included children and adolescents living with achondroplasia and/or their caregivers. Caregivers of children aged 0-7 were interviewed alone, while children/adolescents aged 8-17 participated alongside their caregivers. Participants were identified via a specialist recruitment agency or an advocacy organization representing the community with achondroplasia, who identified participants through social media advertisements and research databases. All participants provided written informed consent/assent and ethics approval was granted by New England Independent Review Board (\#20200883). Eligibility criteria are provided in Table 1. Clinical characteristics, including diagnosis, were collected through parent-report as this study was conducted April-December 2020 during the height of the COVID-19 pandemic and it was not feasible for most participants to obtain clinician-reported data.

Table 1. Eligibility criteria 


\begin{tabular}{|c|c|c|}
\hline Criteria & Inclusion criteria & Exclusion \\
\hline \multirow{2}{*}{$\begin{array}{l}\text { Demographics } \\
\text { (child/adolescent } \\
\text { living with } \\
\text { achondroplasia) }\end{array}$} & $\begin{array}{l}\text { - Child is male or } \\
\text { female, aged } 0-17 \\
\text { years }\end{array}$ & \multirow[t]{2}{*}{ - No restrictions } \\
\hline & $\begin{array}{l}\text { - (For } \\
\text { children/adolescents } \\
\text { participating in } \\
\text { interview) Child is } \\
\text { fluent in US-English }\end{array}$ & \\
\hline \multirow[t]{3}{*}{$\begin{array}{l}\text { Demographics } \\
\text { (caregiver) }\end{array}$} & $\begin{array}{l}\text { - Caregiver is a } \\
\text { primary caregiver to } \\
\text { the child with } \\
\text { achondroplasia, and } \\
\text { lives with them on a } \\
\text { full-time basis }\end{array}$ & \multirow[t]{3}{*}{ - No restrictions } \\
\hline & $\begin{array}{l}- \text { Caregiver is aged } \\
\geq 18 \text { years }\end{array}$ & \\
\hline & $\begin{array}{l}\text { - Caregiver is fluent } \\
\text { in US-English }\end{array}$ & \\
\hline \multirow[t]{3}{*}{$\begin{array}{l}\text { Diagnosis and } \\
\text { treatment } \\
\text { (child/adolescent } \\
\text { living with } \\
\text { achondroplasia) }\end{array}$} & \multirow[t]{3}{*}{$\begin{array}{l}\text { - Child has a clinical } \\
\text { diagnosis of } \\
\text { achondroplasia }\end{array}$} & $\begin{array}{l}\text { - Child has a diagnosis of hypochondroplasia or any } \\
\text { short stature condition other than achondroplasia (e.g., } \\
\text { spondyloepiphyseal dysplasia congenital, } \\
\text { pseudoachondroplasia, trisomy 21) }\end{array}$ \\
\hline & & $\begin{array}{l}\text { - Child has any medical condition that may impact } \\
\text { growth or where the treatment is known to impact } \\
\text { growth, such as but not limited to hypothyroidism or } \\
\text { hyperthyroidism, insulin-requiring diabetes mellitus, } \\
\text { autoimmune inflammatory disease (including celiac } \\
\text { disease, lupus nephritis, juvenile dermatomyositis, } \\
\text { scleroderma, and others), autonomic neuropathy, or } \\
\text { inflammatory bowel disease }\end{array}$ \\
\hline & & $\begin{array}{l}\text { - Child has a history of limb lengthening surgery } \\
\text { (defined as distraction osteogenesis, Lazaro/callostasis } \\
\text { technique following submetaphyseal osteotomy to } \\
\text { extend bone length) }\end{array}$ \\
\hline \multirow[t]{2}{*}{$\begin{array}{l}\text { Informed } \\
\text { consent }\end{array}$} & $\begin{array}{l}\text { - Child (where } \\
\text { appropriate) and } \\
\text { caregiver are willing } \\
\text { and able to attend a } \\
90 \text {-minute (Round 1) } \\
\text { or } 60 \text {-minute (Round } \\
\text { 2) interview }\end{array}$ & \multirow[t]{2}{*}{$\begin{array}{l}\text { - Participant has any concurrent clinically significant } \\
\text { major disease or condition that the investigator deems } \\
\text { unsuitable for participation or other acute or chronic } \\
\text { medical or psychiatric condition, which would also } \\
\text { impair their ability to participate in the study }\end{array}$} \\
\hline & $\begin{array}{l}\text { - Child (where } \\
\text { appropriate) will } \\
\text { sign assent forms to } \\
\text { be in the study; their } \\
\text { caregiver will sign a } \\
\text { consent form }\end{array}$ & \\
\hline
\end{tabular}




\section{Interview procedures}

A semi-structured interview guide was developed by COA experts and was reviewed by a patient advocate and clinical expert in achondroplasia. Interviews were conducted by experienced qualitative interviewers using telephone and/or video conferencing software to allow screen sharing and video participation. Interviews lasted 60-90 minutes, were audio-recorded and transcribed verbatim. All interviewers had Collaborative Institutional Training Initiative (CITI) Human Subjects Research certification, were trained in COA interview techniques, and attended study-specific training sessions to standardize techniques.

Interviews were conducted in two rounds to allow for adjustments to be made to the COA measures and subsequent testing; Round 1 interviews comprised combined concept elicitation and cognitive debriefing, while Round 2 interviews focused on cognitive debriefing. During concept elicitation, participants were asked open-ended questions regarding the signs, symptoms, and impacts of achondroplasia, including which aspects of achondroplasia they found most bothersome, and outcomes that they may find most meaningful following treatment. During cognitive debriefing, participants were asked to complete the CHAQ and QoLISSY-Brief measures using 'think-aloud' techniques to explore relevance and understanding. Caregivers completing the interviews alone reviewed the ObsRO versions of the measures, while children/adolescents participating alongside their caregivers were encouraged to attempt to complete the PRO version; if this was too difficult, the interviewer suggested switching to the ObsRO version.

\section{Description of measures}

\section{Childhood Health Assessment Questionnaire (CHAQ)}

The CHAQ is a generic measure comprising 30 items assessing the impact of illness on physical functioning, plus two 0-100 Visual Analogue Scale (VAS) items to assess pain and global health. Each physical functioning item is rated on a 4-point Likert scale according to the amount of difficulty the child has experienced performing the activity in the given recall period ('over the past week'). An additional 'not applicable' response is provided for activities that are not age-appropriate, and respondents are also asked to mark whether any aids, devices or assistance are required to perform each of the listed tasks. The CHAQ is recommended for use with children aged $0-19$ years old; self-report (PRO completion) is recommended for children aged $\geq 8$ years, while caregiver report (ObsRO completion) is recommended for children $<8$ years old $(28,29)$. The wording, layout, and concepts measured in the CHAQ are consistent across the ObsRO and PRO versions of the measure, the only difference being references to 'your child' versus 'you.' Before the Round 1 interviews, references to 'illness' were replaced with 'achondroplasia' as many do not consider achondroplasia to be an illness, and to allow respondents to distinguish between achondroplasia and concurrent conditions.

\section{Quality of Life in Short Stature Youth (QoLISSY-Brief)}


The QoLISSY-Brief is a condition-specific measure comprising nine items, with a 5-point Likert scale assessing the frequency of impact of short height on emotional/social well-being. No recall period is specified. The self-report version (PRO) of the questionnaire is recommended for children aged 8-18 years old and a caregiver-report (ObsRO) version is available for children aged $4-18$ years old (30). The wording, layout, and concepts measured in the QoLISSY-Brief are consistent across the ObsRO and PRO versions of the measure, the only difference being references to 'my child' versus 'me.'

\section{Analysis}

Interview transcripts were reviewed in full and all identifying information (e.g., names and locations) were removed. Participants were assigned a unique ID code to allow anonymous reporting. ID codes included a recruitment number, age group, and denoted whether the speaker is the child/adolescent $(P)$ or their caregiver (CG). For example, the ID code '01-[8-11]-P' refers to a child aged 8-11 years old and '01-[8-11]$\mathrm{CG}^{\prime}$ is their caregiver.

\section{Concept elicitation}

The analysis took a phenomenological interpretive approach (31) and thematic analysis (using ATLAS.ti software, version 7.5) was used to explore open-ended data (32).

\section{Conceptual model development}

A draft conceptual model of the signs, symptoms, and impacts of achondroplasia had previously been developed based on findings from a targeted review of the qualitative literature (12-24) the transcript of a 2018 FDA advisory committee meeting discussing drug development for the treatment of children with achondroplasia (25) and interviews with five expert clinicians. This model was further refined to capture the concepts discussed in the qualitative interviews, and was reviewed and approved by a patient advocate. Items from each COA measure were cross-checked against the concepts identified in the conceptual model to establish the conceptual coverage of the CHAQ and QoLISSY-Brief.

\section{Conceptual saturation}

Conceptual saturation is defined as the point at which no new concept-relevant information emerges (33). When saturation is reached, this is an indication that comprehensive understanding of the participant experience has been achieved, and therefore no further interviews are required. Conceptual saturation was assessed on the basis of concepts arising during concept elicitation. Following industry standards, the interview transcripts were grouped into four sets containing an equal number of transcripts each in the sequential order they were performed and the elicited concepts were compared between sets $(27,34)$; depth of understanding of each concept was also reviewed (33).

\section{Cognitive debriefing}


Data obtained via cognitive debriefing methods were subject to framework coding whereby a pre-defined code list was applied to identify the relevance and appropriateness of item wording, response options and recall period of each COA measure.

\section{Results}

\section{Sample}

A total of 48 interviews were conducted; 36 combined concept elicitation and cognitive debriefing interviews during Round 1 and a further 12 cognitive debriefing interviews in Round 2. Demographic and clinical characteristics of participants are presented in Table 2.

Table 2. Participant characteristicst 


\begin{tabular}{|c|c|c|c|c|}
\hline & \multicolumn{2}{|c|}{ Round $1(\mathrm{~N}=36)$} & \multicolumn{2}{|c|}{ Round 2 ( $N=12)$} \\
\hline & $\begin{array}{l}\text { Children/ } \\
\text { Adolescents }\end{array}$ & Caregivers & $\begin{array}{l}\text { Children/ } \\
\text { Adolescents }\end{array}$ & Caregivers \\
\hline Age, Mean (SD) [Range] & $8(4)$ [1-15] & $\begin{array}{l}40(6)[26- \\
50]\end{array}$ & 7 (6) [1-16] & $\begin{array}{l}39(7)[31- \\
50]\end{array}$ \\
\hline $0-2, n(\%)$ & $8(22)$ & - & $3(25)$ & - \\
\hline $3-7, n(\%)$ & $7(19)$ & - & $5(42)$ & - \\
\hline $8-11, \mathrm{n}(\%)$ & $15(42)$ & - & $1(8)$ & - \\
\hline $12-17, \mathrm{n}(\%)$ & $6(17)$ & - & $3(25)$ & - \\
\hline \multicolumn{5}{|l|}{ Gender, n (\%) } \\
\hline Male & $23(64)$ & $7(19)$ & $5(42)$ & $1(8)$ \\
\hline Female & $13(36)$ & $29(81)$ & $7(58)$ & $11(92)$ \\
\hline \multicolumn{5}{|l|}{ Ethnicity ${ }^{\ddagger}, \mathrm{n}(\%)$} \\
\hline Arabic & $1(3)$ & $1(3)$ & 0 & 0 \\
\hline Asian & $3(8)$ & 0 & $1(8)$ & 0 \\
\hline $\begin{array}{l}\text { Black or African } \\
\text { American }\end{array}$ & $4(11)$ & $3(8)$ & $2(17)$ & $1(8)$ \\
\hline White & $24(67)$ & $28(78)$ & $11(92)$ & $11(92)$ \\
\hline Hispanic & 0 & 0 & $1(8)$ & $1(8)$ \\
\hline Do not wish to answer & $5(14)$ & $5(14)$ & 0 & 0 \\
\hline \multicolumn{5}{|c|}{ Caregiver relationship to child/adolescent, n (\%) } \\
\hline Parent & - & $36(100)$ & - & $12(100)$ \\
\hline \multicolumn{5}{|c|}{ Highest level of education completed, n (\%) } \\
\hline $\begin{array}{l}\text { High school, no } \\
\text { diploma }\end{array}$ & - & $1(3)$ & - & 0 \\
\hline High school diploma & - & $7(19)$ & - & $1(8)$ \\
\hline Associate's degree & - & $5(14)$ & - & $5(42)$ \\
\hline Bachelor's degree & - & $14(39)$ & - & $4(33)$ \\
\hline Graduate degree & - & $9(25)$ & - & $2(17)$ \\
\hline \multicolumn{5}{|l|}{ Diagnosis, n (\%) } \\
\hline Before birth & $16(44)$ & - & $6(50)$ & - \\
\hline
\end{tabular}




\begin{tabular}{|c|c|c|c|c|}
\hline & \multicolumn{2}{|c|}{ Round $1(\mathrm{~N}=36)$} & \multicolumn{2}{|c|}{ Round 2 ( $N=12)$} \\
\hline & $\begin{array}{l}\text { Children/ } \\
\text { Adolescents }\end{array}$ & Caregivers & $\begin{array}{l}\text { Children/ } \\
\text { Adolescents }\end{array}$ & Caregivers \\
\hline At/after birth & $20(56)$ & - & $6(50)$ & - \\
\hline \multicolumn{5}{|l|}{ Treatment history, n (\%) } \\
\hline Vosoritide & $1(3)$ & - & 0 & - \\
\hline Surgery§ & $17(47)$ & - & $8(67)$ & - \\
\hline None & $18(50)$ & - & $4(33)$ & - \\
\hline \multicolumn{5}{|c|}{ Concomitant conditions, n (\%) } \\
\hline Respiratory disease & $1(3)$ & - & $1(8)$ & - \\
\hline None & $35(97)$ & - & $11(92)$ & - \\
\hline
\end{tabular}

Abbreviations: SD, standard deviation

† All data are caregiver-reported

‡ Not mutually exclusive; participants could select multiple responses

$\S$ Including (not mutually exclusive): decompression surgeries ( $n=14,29 \%)$, adenoidectomy $(n=13,27 \%)$, tonsillectomy $(n=11,23 \%)$, ear tube insertion $(n=9,19 \%)$, and others

\section{Child/adolescent experience of achondroplasia}

A conceptual model of the lived experience of children and adolescents with achondroplasia is presented in Figure 1. During the Round 1 interviews, pain $(n=25,69 \%)$ was the most frequently reported symptom of achondroplasia, and difficulties reaching $(n=36,100 \%)$, walking $(n=34,94 \%)$, and toileting $(n=32,89 \%)$ were commonly reported impacts on physical function. Thirty participants (83\%) reported on how developmental milestones varied in comparison with children without achondroplasia, including insights into motor development and speech development. Frequency reports and example quotes are provided in Additional File 1. Twenty concepts identified in prior clinician interviews did not arise during the child/caregiver qualitative interviews; these were mostly clinical sign/symptom concepts.

\section{Most bothersome aspects of achondroplasia}

Children/caregivers named difficulty reaching, pain, short height, and disproportionality (short limbs) amongst the three most bothersome aspects of achondroplasia (Table 3 ). However, disproportionality was not reported among the most bothersome by adolescents aged 12-17 years, and pain and short height were not reported among the most bothersome by caregivers of children aged 0-2 years. Among 
these youngest children, caregivers reported difficulties with movement and health problems (e.g. frequent ear infections) as most bothersome.

Table 3. Top three most bothersome aspects of living with achondroplasia 


\begin{tabular}{|c|c|c|c|c|c|c|}
\hline \multirow[t]{2}{*}{ Concept } & \multicolumn{5}{|c|}{$\begin{array}{l}\text { No. participants naming concept amongst } \\
\text { top } 3 \text { most bothersome aspects of } \\
\text { achondroplasia }\end{array}$} & \multirow[t]{2}{*}{ Example quotes } \\
\hline & $\begin{array}{l}0-2 \\
(\mathrm{~N}=7)\end{array}$ & $\begin{array}{l}3-7 \\
(\mathrm{~N}=7)\end{array}$ & $\begin{array}{l}8-11 \\
(\mathrm{~N}=12)\end{array}$ & $\begin{array}{l}12-17 \\
(\mathrm{~N}=6)\end{array}$ & $\begin{array}{l}\text { Total } \\
(\mathrm{N}=32) *\end{array}$ & \\
\hline Reaching & 1 & 2 & 5 & 3 & 11 & $\begin{array}{l}\text { - 05-[12-17]-P: Reaching the top } \\
\text { shelf. [...] I use a step stool, but } \\
\text { there have been places where } \\
\text { there have been no step stools. } \\
\text { [...] Once in a while, there'll be a } \\
\text { situation where I just can't } \\
\text { reach things, at all. }\end{array}$ \\
\hline Pain & 0 & 1 & 4 & 5 & 10 & $\begin{array}{l}\text { - 32-[8-11]-P: Knee pain. } \\
\text { Sometimes when we go on a } \\
\text { field trip and we're doing hiking, } \\
\text { sometimes we have to leave } \\
\text { early because my knees are } \\
\text { killing me. }\end{array}$ \\
\hline Short height & 0 & 3 & 2 & 3 & 8 & $\begin{array}{l}\text { - 08-[3-7]-CG: It's his height, [...] } \\
\text { 'cause he's shorter than } \\
\text { everyone and it makes } \\
\text { sometimes him feel like he's } \\
\text { the baby. }\end{array}$ \\
\hline $\begin{array}{l}\text { Disproportionality } \\
\text { (Short limbs) }\end{array}$ & 3 & 2 & 2 & 0 & 7 & $\begin{array}{l}\text { - 07-[3-7]-CG: I think a big thing } \\
\text { would be that her arms would } \\
\text { be longer, so that she could } \\
\text { reach and do what she wants } \\
\text { easier. }\end{array}$ \\
\hline Health issues & 3 & 1 & 2 & 0 & 6 & $\begin{array}{l}\text { - 20-[0-2]-CG: He was on } \\
\text { antibiotics all the time for ear } \\
\text { infections. }\end{array}$ \\
\hline $\begin{array}{l}\text { Unable to } \\
\text { participate; } \\
\text { Keeping up with } \\
\text { peers }\end{array}$ & 2 & 1 & 1 & 1 & 5 & $\begin{array}{l}\text {-01-[12-17]-P: Not being able to } \\
\text { do sports that I really enjoy, } \\
\text { and not being able to do them } \\
\text { with my friends. }\end{array}$ \\
\hline \multirow[t]{2}{*}{$\begin{array}{l}\text { Negative } \\
\text { attention/ } \\
\text { comments }\end{array}$} & \multirow[t]{2}{*}{0} & \multirow[t]{2}{*}{0} & \multirow[t]{2}{*}{4} & \multirow[t]{2}{*}{1} & \multirow[t]{2}{*}{5} & $\begin{array}{l}\text { - 31-[8-11]-P: Um, staring and } \\
\text { pointing. }\end{array}$ \\
\hline & & & & & & $\begin{array}{l}\text {-39-[8-11]-P: When people } \\
\text { laugh. }\end{array}$ \\
\hline $\begin{array}{l}\text { Physical } \\
\text { activities }\end{array}$ & 0 & 0 & 4 & 1 & 5 & $\begin{array}{l}\text {-06-[8-11]-P: Not being able to } \\
\text { run as fast, or walk longer } \\
\text { distances. }\end{array}$ \\
\hline $\begin{array}{l}\text { Limited } \\
\text { independence }\end{array}$ & 2 & 1 & 1 & 0 & 4 & $\begin{array}{l}\text { - 30-[3-7]-CG: The being } \\
\text { independent, as far as, like, } \\
\text { reaching things and that type } \\
\text { of thing. }\end{array}$ \\
\hline
\end{tabular}




\begin{tabular}{|c|c|c|c|c|c|c|}
\hline \multirow[t]{2}{*}{ Concept } & \multicolumn{5}{|c|}{$\begin{array}{l}\text { No. participants naming concept amongst } \\
\text { top } 3 \text { most bothersome aspects of } \\
\text { achondroplasia }\end{array}$} & \multirow[t]{2}{*}{ Example quotes } \\
\hline & $\begin{array}{l}0-2 \\
(\mathrm{~N}=7)\end{array}$ & $\begin{array}{l}3-7 \\
(N=7)\end{array}$ & $\begin{array}{l}8-11 \\
(\mathrm{~N}=12)\end{array}$ & $\begin{array}{l}12-17 \\
(\mathrm{~N}=6)\end{array}$ & $\begin{array}{l}\text { Total } \\
(\mathrm{N}=32) *\end{array}$ & \\
\hline $\begin{array}{l}\text { Motor } \\
\text { development }\end{array}$ & 3 & 0 & 0 & 0 & 3 & $\begin{array}{l}\text { - 29-[0-2]-CG: Not being able to } \\
\text { move the way he wants to, is } \\
\text { definitely number one. }\end{array}$ \\
\hline $\begin{array}{l}\text { Frequent } \\
\text { appointments/ } \\
\text { hospitalizations }\end{array}$ & 2 & 1 & 0 & 0 & 2 & $\begin{array}{l}\text { - 29-[0-2]-CG: The medical stuff, } \\
\text { the physical stuff, it's just been } \\
\text { his life from the beginning. [...] } \\
\text { He just wants to be okay. He. } \\
\text { wants to be normal, and he just } \\
\text { gets kind of upset about it, } \\
\text { pretty frequently, actually. }\end{array}$ \\
\hline $\begin{array}{l}\text { Limited mobility/ } \\
\text { range of motion }\end{array}$ & 0 & 2 & 0 & 0 & 2 & $\begin{array}{l}\text { - 14-[3-7]-CG: A dexterity thing. } \\
\text { Like, being able to hold things } \\
\text { in his arms, being able to catch } \\
\text { balls easier, that sort of thing } \\
\text { would be huge for him. }\end{array}$ \\
\hline $\begin{array}{l}\text { Speech } \\
\text { development }\end{array}$ & 1 & 0 & 0 & 0 & 1 & - 20-[0-2]-CG: The speech delay. \\
\hline $\begin{array}{l}\text { Limited clothing } \\
\text { options }\end{array}$ & 0 & 0 & 0 & 1 & 1 & $\begin{array}{l}\text { - 04-[12-17]-P: Clothes is really } \\
\text { annoying and, like, having } \\
\text { small feet, like, now, like, } \\
\text { especially when I was younger, } \\
\text { and, like, only, like, the Velcro } \\
\text { shoes were in my size and } \\
\text { stuff, and, like, now, like, if I } \\
\text { want a shoe, they're not in my } \\
\text { size, it's definitely annoying } \\
\text { and clothes. }\end{array}$ \\
\hline
\end{tabular}

*Due to interview time constraints, $n=4$ participants did not complete this activity

\section{Treatment outcomes}

Fourteen caregivers of children aged 0-7 years were asked whether an increase in height and/or an increase in limb proportionality would be a meaningful treatment outcome. Nine caregivers $(n=9 / 14,64 \%)$ considered an increase in height a successful/ somewhat successful treatment outcome as this would help their child to be more independent, improve their quality of life and make the challenges faced in everyday life easier.

- 25-[3-7]-CG: I feel like it would make her be more independent in the world out here. Because, again, it's not made for people with achondroplasia, and she wouldn't have to depend on someone to do things for her, if she had more height. 
Eleven caregivers $(n=11 / 14,71 \%)$ reported an increase in limb proportion would be considered a successful/ somewhat successful treatment outcome because this would allow their child to be more independent, provide greater reach and allow independent self-care, reduce the need for aids, and improve balance.

- 20-[0-2]-CG: It would make it a little easier for him to do certain things, like get dressed, be able to use the bathroom, maybe not have to have as long as pedal extensions to drive a car in the future, or maybe not have to use stools or rely on those so much, 'cause the outside world is not built for someone with achondroplasia

- 02-[0-2]-CG: You know, especially arm length, I think, would be really helpful. And well, I think it would be more meaningful than just added height overall.

However, $n=5$ caregivers felt that an increase in limb proportionality and/or an increase in height would not be meaningful treatment outcomes; some would not consider any treatment at all $(n=2 / 14,14 \%)$ because they did not want to change their child, and others prioritized reduction in the risk of serious health conditions over increased height $(n=3 / 14,21 \%)$ or improved limb proportionality $(n=1 / 14,7 \%)$.

- 08-[3-7]-CG: No. Wouldn't want it. Wouldn't even use it. No. Because God made us who we are for a reason, and why change the way you are?

\section{Saturation analysis}

A full understanding of each of the concepts arising in the qualitative interviews was obtained, and most $(n=94 / 96,98 \%)$ of these concepts arose spontaneously within the first three sets of interviews; saturation was deemed to have been met by the end of Round 1 .

\section{Relevance and appropriateness of the CHAQ}

\section{Conceptual relevance}

The CHAQ had good conceptual coverage of the physical limitations often experienced by children/adolescents with achondroplasia, and each item was reported as relevant by at least $n=2$ participants. Items evaluating difficulties with reach $(n=33,92 \%)$ and difficulties with activities of daily living (e.g. turn faucets on and off, $n=22,61 \%$; dress, $n=20,56 \%$; comb/brush hair, $n=19,53 \%$ ) were particularly relevant, and a domain importance exploration identified that the 'hygiene' and 'reach' domains were the functions that children/adolescents with achondroplasia would most like a treatment to address.

The need for assistance using aids/devices or help from another person are factored into the CHAQ scoring. A list of aids/devices is presented, alongside a write-in response box for 'other' items. During Round 1, 27 participants made use of the 'other' option noting that they needed a step stool $(\mathrm{n}=22)$, lightswitch extender $(n=6)$, and devices for toileting $(n=4)$. 
Comparison of the items of the CHAQ against the conceptual model demonstrated good conceptual coverage of the 'impact on physical functioning' concepts, including the four most frequently reported impacts on motor skills and the nine most frequently reported impacts on activities of daily living (see Figure 1).

\section{Understanding}

\section{Item wording}

Many children in the age 8-11 subgroup experienced difficulties reading and/or understanding words included in the measure. One child was unable to attempt to read the measure at all, while others required caregiver input to read and/or understand specific phrases. Caregivers and adolescents aged 12-17 were overall able to complete the measure without difficulty, although some experienced difficulties with some sections of the measure.

Reading the measure instructions, three caregivers noted that it may be difficult to know what 'most children at your child's age' are expected to do, and one caregiver reported that it may be difficult for them to think about whether their child's limitations are due to achondroplasia. Completing the items of the measure, six caregivers misinterpreted the section heading of 'arising' to mean waking up in the morning, rather than, for example, standing up from a low chair or floor. Five caregivers and one adolescent were unfamiliar with one or more of the devices listed, and participants often interpreted these items to ask about any aids or devices used due to achondroplasia, rather than those specific to the activities listed. Finally, three caregivers had difficulty understanding the section heading 'Global evaluation.'

\section{Response options}

All caregivers were able to use the Likert scale response options as written to select an answer to each item, but four children aged 8-11 and one adolescent aged 12-17 struggled to understand the 'not applicable' response option. All participants were able to use the 0-100 VAS as presented to complete the pain and global evaluation items, but six felt they would be easier to interpret if the anchors were reversed and four found it difficult to choose where to place a mark along the scale.

\section{Recall period}

Overall, most participants were able to understand the recall period and respond to all items appropriately, but two caregivers and three children aged 8-11 had difficulty understanding the phrasing "averaged over an entire day, over the past week".

Two caregivers, three children aged 8-11 and one adolescent aged 12-17 described an incorrect recall period when asked by the interviewer, for example, the past few years $(n=2)$, or the past day $(n=1)$.

\section{ObsRO: Observable concepts}


All caregivers could rate the majority of $\mathrm{CHAQ}$ items through observing their child, with most items assessing observable activities. However, six caregivers reported some difficulty in observing/rating pain severity.

\section{Modifications}

Based on Round 1 interview feedback, the CHAQ was amended to improve usability and understanding. These modifications form the CHAQ (adapted for achondroplasia) and are summarized in Table 4. ObsRO completion was identified as most suitable for children aged 0-11 and PRO completion by adolescents aged 12-17 only.

Table 4. Modifications made to the CHAQ (adapted for achondroplasia)

\begin{tabular}{|c|c|c|}
\hline Element & Edit & Rationale \\
\hline Instructions & $\begin{array}{l}\text { Shortened and } \\
\text { simplified } \\
\text { wording }\end{array}$ & To make them easier to understand. \\
\hline Recall period & $\begin{array}{l}\text { Change to 'Over } \\
\text { the past } 7 \text { days' }\end{array}$ & $\begin{array}{l}\text { The instruction to 'average' difficulties experienced 'over } \\
\text { an entire day' is not applicable to achondroplasia and } \\
\text { several participants found the original description of the } \\
\text { recall period to be confusing. }\end{array}$ \\
\hline 'Arising' & $\begin{array}{l}\text { Replacement of } \\
\text { 'Arising' with } \\
\text { 'Getting Up' }\end{array}$ & 'Getting up' may better describe the applicable concepts \\
\hline $\begin{array}{l}\text { 'Aids and devices' } \\
\text { items }\end{array}$ & $\begin{array}{l}\text { Capitalization of } \\
\text { "...any of the } \\
\text { ABOVE activities." }\end{array}$ & $\begin{array}{l}\text { To draw participants' attention that only aids/devices } \\
\text { used during completion of the associated activities } \\
\text { should be considered. }\end{array}$ \\
\hline $\begin{array}{l}\text { Aids and devices } \\
\text { ('hygiene,' 'reach,' } \\
\text { 'gripping and } \\
\text { opening things', } \\
\text { 'errands and } \\
\text { chores') }\end{array}$ & $\begin{array}{l}\text { Addition of 'step } \\
\text { stool' as a listed } \\
\text { aid/device and } \\
\text { inclusion of an } \\
\text { 'other' option }\end{array}$ & $\begin{array}{l}\text { To improve relevance of the measure to achondroplasia } \\
\text { and reduce likelihood that participants fail to } \\
\text { acknowledge use of a step stool. }\end{array}$ \\
\hline $\begin{array}{l}\text { 'Global evaluation' } \\
\text { item }\end{array}$ & $\begin{array}{l}\text { Removal of } \\
\text { 'Global } \\
\text { Evaluation' } \\
\text { heading }\end{array}$ & To make the item easier to complete. \\
\hline $\begin{array}{l}\text { 'Pain' and 'global } \\
\text { evaluation' response } \\
\text { scales }\end{array}$ & $\begin{array}{l}\text { Replacement of } \\
0-100 \text { VAS with } \\
0-10 \text { NRS }\end{array}$ & $\begin{array}{l}\text { A } 0-10 \text { NRS is easier to complete than a } 0-100 \text { VAS } \\
\text { due to the clear numeric response options, and removes } \\
\text { risk of inconsistencies in the length of the VAS scale } \\
\text { due to formatting/printing of pen and paper measures. }\end{array}$ \\
\hline $\begin{array}{l}\text { ‘Pain' response } \\
\text { scale }\end{array}$ & $\begin{array}{l}\text { Change anchors } \\
\text { to 'No pain' and } \\
\text { 'Worst pain } \\
\text { imaginable' }\end{array}$ & $\begin{array}{l}\text { These anchors are generally considered most } \\
\text { appropriate for pain measurement. }\end{array}$ \\
\hline
\end{tabular}


Abbreviations: NRS, numeric rating scale; VAS, visual analogue scale

In Round 2, participants cognitively debriefed the revised measure. Conceptual relevance was consistent with Round 1 results, and all items, response options and the revised instructions were well understood by all caregivers and adolescents.

\section{Relevance and appropriateness of the QoLISSY-Brief}

\section{Conceptual relevance}

The QoLISSY-Brief had good conceptual coverage of impacts of achondroplasia on emotional/social well-being, and each item was reported as relevant by at least a third of the sample. The nine items of the measure assess 13 of the concepts on the conceptual model (some items map to more than one concept), although this does not include the most frequently reported emotional and psychological impact 'frustrated' or any impacts relating to school/day care.

\section{Understanding}

\section{Item wording}

As with the CHAQ, many children in the age 8-11 subgroup experienced difficulties reading/and or understanding the QoLISSY-Brief. However, all caregivers and most adolescents aged 12-17 interpreted and completed the measure without difficulty; two adolescents struggled to understand the meaning of 'insecure.'

\section{Response options}

All participants ( $N=22 ; n=17$ caregivers; $n=5$ children) were able to use the response options as written to select an answer to each item.

\section{Recall period}

The QoLISSY-Brief lacks a defined recall period. Following debriefing, $\mathrm{N}=27$ participants were asked about the time frame they were thinking about while completing the items, and responses varied substantially (Table 5). Two participants commented that the lack of recall period made it difficult to select a response because their answer would depend on the time frame considered.

Table 5. Recall periods used by participants while completing the QoLISSY-Brief 


\begin{tabular}{|c|c|c|}
\hline $\begin{array}{l}\text { Recall } \\
\text { period } \\
\text { used }\end{array}$ & $\begin{array}{l}n(\%) \\
(\mathrm{N}=27)\end{array}$ & Example quote \\
\hline $\begin{array}{l}\text { Non- } \\
\text { specific }\end{array}$ & $6(22)$ & $\begin{array}{l}\text { 13-[12-17]-P: Recently, but also, kind of, the general picture because, again, not } \\
\text { having much experience with the general public right now. }\end{array}$ \\
\hline $\begin{array}{l}\text { Right } \\
\text { now/ } \\
\text { today }\end{array}$ & $5(21)$ & $\begin{array}{l}\text { 20-[0-2]-CG: Um, I was trying to kind of think about him and his reactions and } \\
\text { how he- his personality and how he acts today. }\end{array}$ \\
\hline $\begin{array}{l}\text { Past } \\
\text { week }\end{array}$ & $1(4)$ & 201-[0-2]-CG: Just in the past, like the past week. \\
\hline $\begin{array}{l}\text { Past } \\
\text { two } \\
\text { weeks }\end{array}$ & $2(7)$ & 18-[8-11]-P: I was thinking about a couple of weeks ago, I think. \\
\hline $\begin{array}{l}\text { Past } \\
\text { month }\end{array}$ & $2(7)$ & $\begin{array}{l}\text { 19-[8-11]-P: Like, a little bit far back. [...] Um, a month ago or something like } \\
\text { that. Like, a long time ago, not, like, a week, a long time ago. }\end{array}$ \\
\hline $\begin{array}{l}\text { Past } \\
\text { few } \\
\text { months }\end{array}$ & $5(21)$ & $\begin{array}{l}\text { 38-[8-11]-CG: In just the last, you know, for a while. I mean, um, say few } \\
\text { months or something like that. In the, in the, in the present or, or near-term past. } \\
\text { Yeah. }\end{array}$ \\
\hline $\begin{array}{l}\text { Past } \\
\text { year }\end{array}$ & $1(4)$ & 15-[12-17]-P: Probably within the last year. \\
\hline $\begin{array}{l}\text { Past } 1- \\
2 \text { years }\end{array}$ & $3(11)$ & 01-[12-17]-P: Mostly in the past, like, year or two. \\
\hline $\begin{array}{l}\text { Entire } \\
\text { life }\end{array}$ & $2(7)$ & $\begin{array}{l}\text { 05-[3-7]-CG: I was thinking about, like, his entire life here, when I answered the } \\
\text { questions. }\end{array}$ \\
\hline
\end{tabular}

\section{ObsRO: Observable concepts}

All caregivers could provide a response to all items and most found it easy to complete. However, some difficulty was reported for non-observable concepts (e.g. feel bothered, feel different, feel small, feel insecure).

\section{Modifications}

One change was made to the QoLISSY-Brief based on the feedback obtained during the Round 1 interviews; a recall period of seven days was added to the measure with the instruction 'Thinking about the past 7 days:' prefacing the items. In addition, as with the CHAQ (adapted for achondroplasia), ObsRO completion was identified as most suitable for children aged 0-11 with PRO completion most suitable for adolescents aged 12-17 only.

In Round 2, participants cognitively debriefed the revised measure. Conceptual relevance and item understanding was consistent with the Round 1 results, and the newly added recall period was well 
understood by all caregivers and adolescents.

\section{Discussion}

The findings from this interview study led to the refinement of a conceptual model of achondroplasia and an in-depth understanding of the impact of achondroplasia on individuals' physical functioning and wellbeing. Discussion of the symptoms and impacts of achondroplasia found that pain, difficulties with physical function/motor skills, and difficulties with activities of daily living are of greatest importance to children and adolescents for measurement in clinical trials for achondroplasia treatments; the majority of functional impacts were discussed in depth by the participants who provided rich insights into these experiences. When queried on factors that could be considered treatment success, caregivers of children and adolescents in this study generally confirmed height and limb proportion were important treatment outcomes, but also voiced an expectation that treatment should address important functional outcomes such as improved reach.

Detailed descriptions of achondroplasia signs/symptoms were obtained, although it should be noted that not all signs/clinical presentations noted in the literature and reported by clinical experts were identified in the qualitative interviews with children and their caregivers. This is not surprising considering that many of the clinical signs/presentation in achondroplasia are heterogeneous, and are likely to be better understood by clinical experts, an important reason for including multiple sources when developing a conceptual model of disease. Similarly, many of the impacts of achondroplasia on well-being discussed in the literature, by clinical experts, and/or at the FDA advisory committee meeting did not arise in these interviews. However, it should be noted that emotional and psychological concepts were not probed in detail in interviews where the child was present to avoid causing undue upset, and therefore the reported frequency of these impacts may be under-represented. In addition, several participating caregivers noted during the interviews they themselves also lived with achondroplasia. As such, some children/adolescents were living in houses that had already been adapted for their parent/caregiver's achondroplasia (for example, bungalows with no stairs) and the impact could be lessened than for those whose environment had not been previously adapted. Additionally in some cases where children who lived with other family members with achondroplasia, such as a sibling or parent, the impact on emotional burden could be lesser than those children who were the only family member to live with achondroplasia.

The CHAQ (adapted for achondroplasia) has good conceptual coverage of the physical limitations often experienced by children/adolescents with achondroplasia, and amendments made to the original measure instructions, pain/global evaluation response scales, and 'aids and devices' items were found to form an understandable and usable measure.

The QoLISSY-Brief has good conceptual coverage of the impacts on emotional and social well-being often experienced by children and adolescents with achondroplasia. The addition of a defined recall period improves ease of completion and permits the monitoring of changes over time. 
Based on the findings of this interview study, the CHAQ (adapted for achondroplasia) and QoLISSY-Brief, ObsRO completion is recommended for children aged 0-11 with PRO completion by adolescents aged 12-17 only due to the frequency of difficulties reported by younger children. This recommendation for the age group 8-11 years differs from previous recommendations $(28,30)$, however the best reporter should not be based on age alone; developmental ability and the complexity of concepts measured are also relevant factors (26). In this study several children were in a school year younger than was typical for their age.

Limitations of this study are acknowledged. This study was conducted during the height of the COVID-19 pandemic and subsequently it was not possible for most participants to easily and/or safely visit their clinicians to obtain proof of diagnosis and clinician-reported patient treatment history, or for the interviews to be conducted in person. Reported clinical demographics are therefore based on caregiver recall, but nevertheless considered to be accurate as parents were highly engaged with the diagnosis and treatment of their children. Additionally, this study was conducted in the US only and therefore findings may not be generalizable to other countries and cultures. In particular, societal attitudes to achondroplasia may differ country to country which could influence individuals' experiences.

\section{Conclusions}

The CHAQ (adapted for achondroplasia) and QoLISSY-Brief are relevant and appropriate measures of physical function and emotional/social well-being in pediatric achondroplasia. Patient-report versions of the CHAQ (adapted for achondroplasia) and QoLISSY-Brief are recommended for individuals with achondroplasia age 12-17 years and caregiver-report versions are recommended for age $0-11$ years.

\section{List Of Abbreviations}

CHAQ Child Health Assessment Questionnaire

CITI Collaborative Institutional Training Initiative

COA Clinical outcome assessment

NRS Numeric rating scale

ObsRO Observer-reported outcome

PFDD Patient-Focused Drug Development

PRO Patient-reported outcome

QoLISSY Quality of Life in Short Stature Youth

SD Standard deviation

Page 21/26 


\section{Declarations}

\section{Ethics approval and consent to participate}

The study protocol was reviewed and approved by New England Independent Review Board (IRB Protocol Number: 20200883) on 10th April 2020.

\section{Consent for publication}

Not applicable.

\section{Availability of data and materials}

The datasets used and/or analyzed during the current study are available from the corresponding author on reasonable request, and with permission of the study sponsor.

\section{Competing interests}

NVJA, HK, CJ, CM, and HP are employees and stockholders of Clarivate, a health economic and outcomes research consultancy that consults with various pharmaceutical companies, and were paid consultants to Pfizer in connection with this study and the development of this manuscript. CLB and KB are employees and shareholders at Pfizer. SC, SP and KWW were employees at Pfizer when this research was conducted, and are shareholders at Pfizer. CC and JM have no conflicts of interest to declare.

\section{Funding}

This study, including editorial/medical writing support by NVJA, was conducted by DRG Abacus (Part of Clarivate) and sponsored by Pfizer.

\section{Authors' contributions}

KWW, SP, SC, CLB, and HK conceptualized and designed this study and approved the final protocol. NVJA, $\mathrm{HK}, \mathrm{CJ}, \mathrm{CM}, \mathrm{HP}$ conducted interviews and collected and analyzed the study data. KB provided support to obtain patient advocacy reviews. CC provided patient advocacy support and review of the interview guide and critical outputs. JM provided clinical expert review of the interview guide. All authors interpreted the data. All authors read and approved the final manuscript.

\section{Acknowledgements}

The authors thank and acknowledge the children and adolescents living with achondroplasia who bravely participated in this interview study, and their caregivers. 


\section{References}

1. Horton WA, Hall JG, Hecht JT. Achondroplasia. The Lancet. 2007;370(9582):162-72.

2. Pauli RM. Achondroplasia: a comprehensive clinical review. Orphanet journal of rare diseases. 2019;14(1):1.

3. Ireland PJ, Donaghey S, McGILL J, Zankl A, Ware RS, Pacey V, et al. Development in children with achondroplasia: a prospective clinical cohort study. Developmental Medicine \& Child Neurology. 2012;54(6):532-7.

4. Hunter A, Bankier A, Rogers J, Sillence D, Scott C. Medical complications of achondroplasia: a multicentre patient review. Journal of medical genetics. 1998;35(9):705-12.

5. Beals RK, Stanley G. Surgical correction of bowlegs in achondroplasia. Journal of Pediatric Orthopaedics B. 2005;14(4):245-9.

6. Bagley CA, Pindrik JA, Bookland MJ, Camara-Quintana JQ, Carson BS. Cervicomedullary decompression for foramen magnum stenosis in achondroplasia. Journal of Neurosurgery: Pediatrics. 2006;104(3):166-72.

7. Tenconi R, Khirani S, Amaddeo A, Michot C, Baujat G, Couloigner V, et al. Sleep-disordered breathing and its management in children with achondroplasia. American Journal of Medical Genetics Part A. 2017;173(4):868-78.

8. Collins WO, Choi SS. Otolaryngologic manifestations of achondroplasia. Archives of Otolaryngology-Head \& Neck Surgery. 2007;133(3):237-44.

9. Schiedel F, Rödl R. Lower limb lengthening in patients with disproportionate short stature with achondroplasia: a systematic review of the last 20 years. Disability and rehabilitation. 2012;34(12):982-7.

10. Prevision Policy. Rare Disease Drug Developers Should Not Overlook Familiar Endpoints Relevant To Patient Burdens; FDA Is Not Wed To New Endpoints For Each Disease. Report available online at https://www.previsionpolicy.com/rare-disease-drug-developers-should-not-overlook-familiarendpoints-relevant-to-patient-burdens-fda-is-not-wed-to-new-endpoints-for-each-disease. Last accessed 16-Aug-2020. 2019.

11. C-Path. C-Path Receives FDA Grant to Establish Rare Disease Clinical Outcome Assessment Consortium. Press release. Available online at https://c-path.org/c-path-receives-fda-grant-toestablish-rare-disease-clinical-outcome-assessment-consortium/. Last accessed 21-April-2021. 2020.

12. Bloemeke J, Sommer R, Witt S, Bullinger M, Nordon C, Badia FJ, et al. Cross-cultural selection and validation of instruments to assess patient-reported outcomes in children and adolescents with achondroplasia. Quality of Life Research. 2019;28(9):2553-63.

13. Bloemeke J, Sommer R, Witt S, Dabs M, Badia FJ, Bullinger M, et al. Piloting and psychometric properties of a patient-reported outcome instrument for young people with achondroplasia based on the international classification of functioning disability and health: the achondroplasia personal life experience scale (APLES). Disability and rehabilitation. 2019;41(15):1815-25. 
14. Blömeke J. APLES-The Achondroplasia Personal Life Experience Scale-Development of a Questionnaire to Assess Quality of Life, Burden of Disease and Functionality of Children with Achondroplasia: Hochschule für angewandte Wissenschaften Hamburg; 2016.

15. Daniel E, Kent G, Binney V, Pagdin J. Trying to do my best as a mother: Decision-making in families of children undergoing elective surgical treatment for short stature. British Journal of Health Psychology. 2005;10(1):101-14.

16. Haverkamp F, Noeker M. 'Short stature in children-a questionnaire for parents': a new instrument for growth disorder-specific psychosocial adaptation in children. Quality of Life Research. 1998;7(5):447-55.

17. Ireland PJ, Mcgill J, Zankl A, Ware RS, Pacey V, Ault J, et al. Functional performance in young Australian children with achondroplasia. Developmental Medicine \& Child Neurology. 2011;53(10):944-50.

18. Pfeiffer KM, Brod M, Viuff D, Ota S, Gianettoni J, Leff J, editors. Development of a Parent Experience Measure for Parents of Children with Achondroplasia. 58th Annual ESPE; 2019: European Society for Paediatric Endocrinology.

19. Pfeiffer KM BM, Viuff D, Ota S, Gianettoni J, Leff J. Development of a Measure for the Impacts of Pediatric Achondroplasia on Children's Daily Functioning and Well-being. Annual European Society for Paediatric Endocrinology Meeting (ESPE), September 19-21 2019; (Austria, Vienna). 2019.

20. Pfeiffer KM BM, Viuff D, Ota S, Gianettoni J, Leff JA. Pediatric Achondroplasia: Impacts on Children's Functioning and Well-Being. Poster presented at the International Skeletal Dysplasia Society (ISDS) Annual Meeting, September 11-14, 2019 (Oslo, Norway). 2019.

21. Quitmann J, Witt S, Rohenkohl A, Bullinger M, Sommer R, Klingebiel R, et al. Quality of life in young patients with achondroplasia. Qualitative comparison of the perspectives of patients and parents. MONATSSCHRIFT KINDERHEILKUNDE. 2014;162(5):428-+.

22. Sommer R, Blömeke J, Dabs M, Witt S, Bullinger M, Quitmann J. An ICF-CY-based approach to assessing self-and observer-reported functioning in young persons with achondroplasiadevelopment of the pilot version of the Achondroplasia Personal Life Experience Scale (APLES). Disability and rehabilitation. 2017;39(24):2499-503.

23. Witt S. Gesundheitsbezogene Lebensqualität von kleinwüchsigen Kindern, Jugendlichen und jungen ErwachsenenEin Vergleich der Eltern-Kind-Perspektive: Hochschule für angewandte Wissenschaften Hamburg; 2012.

24. Witt S, Rohenkohl A, Bullinger M, Sommer R, Kahrs S, Klingebiel K-H, et al. Understanding, Assessing and Improving Health-Related Quality of Life of Young People with Achondroplasia-A Collaboration between a Patient Organization and Academic Medicine. Pediatric endocrinology reviews: PER. 2017;15(Suppl 1):109-18.

25. FDA. Transcript of the May 11, 2018 Joint Meeting of the Pediatric and Endocrinologic and Metabolic Drugs Advisory Committees. Available online at https://www.fda.gov/media/115942/download. Last accessed 15-April-2021. 2018. 
26. Arbuckle R, Abetz-Webb L. "Not just little adults": qualitative methods to support the development of pediatric patient-reported outcomes. The Patient-Patient-Centered Outcomes Research. 2013;6(3):143-59.

27. FDA. Discussion document for Patient-focused drug development public workshop on guidance 3 : Select, develop or modify fit-for-purpose clinical outcome assessments. Available online at https://www.fda.gov/media/116277/download. Last accessed 16-Aug-2020.

28. Singh G, Athreya BH, Fries JF, Goldsmith DP. Measurement of health status in children with juvenile rheumatoid arthritis. Arthritis \& Rheumatism. 1994;37(12):1761-9.

29. Klepper SE. Measures of pediatric function: The child health assessment questionnaire (CHAQ), juvenile arthritis functional assessment report (JAFAR), juvenile arthritis functional assessment scale (JAFAS), juvenile arthritis functional status index (JASI), and pediatric orthopedic surgeons of north america (POSNA) pediatric musculoskeletal functional health questionnaire. Arthritis Care \& Research: Official Journal of the American College of Rheumatology. 2003;49(S5):S5-S14.

30. Group; TEQ. Quality of Life in Short Stature Youth: The QoLISSY Questionnaire User's Manual. Lengerich, Germany: Pabst Sciences Publishers. 2013.

31. Guest G, MacQueen KM, Namey EE. Applied thematic analysis: Sage Publications; 2011.

32. Braun V, Clarke V. Using thematic analysis in psychology. Qualitative research in psychology. 2006;3(2):77-101.

33. Guest G, Bunce A, Johnson L. How many interviews are enough? An experiment with data saturation and variability. Field methods. 2006;18(1):59-82.

34. Patrick DL, Burke LB, Gwaltney CJ, Leidy NK, Martin ML, Molsen E, et al. Content validityestablishing and reporting the evidence in newly developed patient-reported outcomes (PRO) instruments for medical product evaluation: ISPOR PRO Good Research Practices Task Force report: part 2-assessing respondent understanding. Value in Health. 2011;14(8):978-88.

\section{Figures}




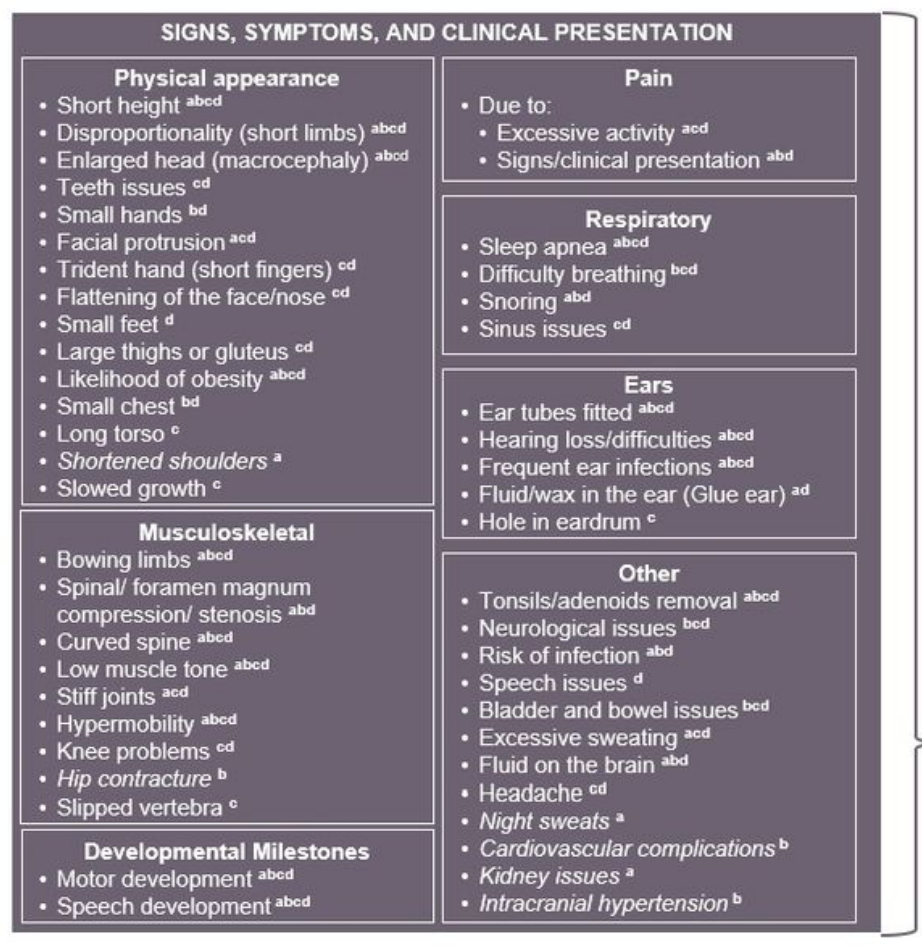

\section{Key}

Concept reported in:

a Clinical expert interviews

bDA advisory committee meeting (2018)

'Literature review

d This study; qualitative interviews with children/adolescents and/or their caregivers

Concepts presented in descending order of reporting frequency in this study, italics indicates a concept reported by clinical experts only

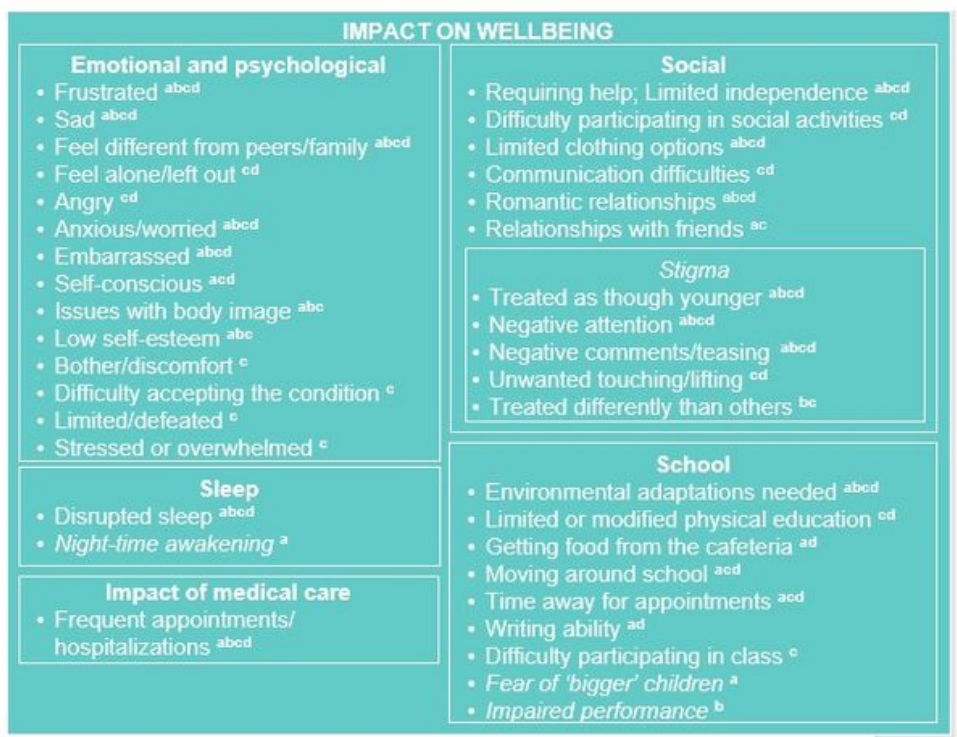

\begin{tabular}{|c|c|}
\hline \multicolumn{2}{|c|}{ IMPACT ON PHYSICAL FUNCTIONING } \\
\hline $\begin{array}{l}\text { Motor skills } \\
\text { - Reaching abcd } \\
\text { - Walking abed } \\
\text { - Running abcd } \\
\text { - Crawling ad } \\
\text { - Sitting for long periods abcd } \\
\text { - Falling over } \\
\text { - Gripping } \\
\text { - Carrying heavy objects } \\
\text { - Fine motor movement } \\
\text { abod } \\
\text { - Balance } \\
\text { - Cycling } \\
\text { - Jumping } \\
\text { - Lifting objects }\end{array}$ & $\begin{array}{l}\text { Activities of daily living* } \\
\text { - Toileting abcd } \\
\text { - Self-care abed } \\
\text { - Climbing in/out of chairs, beds or cars }{ }^{\text {abd }} \\
\text { - Climbing stairs abcd } \\
\text { - Sport/leisure activities/hobbies abed } \\
\text { - Dressing abcd } \\
\text { - Difficulty eating/drinking/feeding abcd } \\
\text { - Opening/closing doors bed } \\
\text { - Traveling } \\
\text { - Cooking } \\
\text { - Seeing over an object/counter bd } \\
\text { - Shopping }{ }^{\text {cd }} \text { Ranges from cannot do these activities } \\
\text { to needs help/adaptations/aids }\end{array}$ \\
\hline $\begin{array}{l}\text { - Transition movements } \\
\text { - Limited range of motion } \\
\text { - Swallowing } \\
\text { - Standing for long periods }\end{array}$ & $\begin{array}{l}\text { Other physical impacts } \\
\text { - Playing (in playground, with toys) } \\
\text { - Keeping up with peers } \\
\text { - Tibed } \\
\text { - Risk of injury abd }\end{array}$ \\
\hline
\end{tabular}

\section{Figure 1}

Conceptual model

\section{Supplementary Files}

This is a list of supplementary files associated with this preprint. Click to download.

- AdditionalFile1.docx 